\title{
GEOGRAPHICAL PARALLELS AND MERIDIANS IN REGIONAL GEOGRAPHY OF HIGH SCHOOL BETWEEN THE REPUBLIC OF MACEDONIA AND THE REPUBLIC OF BULGARIA
}

DOI: http://dx.doi.org/10.18509/GBP.2017.16

UDC: 373.5.016:91(497.7:497.2)

\author{
Stella Dermendzhieva \\ Tamara Draganova \\ St. Cyril and St. Methodius University of Veliko Turnovo, Bulgaria
}

\begin{abstract}
The article analyzes the place, the essence and the features of geography of the countries in school documentation in Macedonia and Bulgaria, in particular curriculums and determines similarities and differences. The applying of territorial, typological and problematic approach at the study of countries are traditionally approved in both educational systems. To establish the facts of comparative research are applied the following methods - content-analysis, situation analysis, comparative analysis, Vennanalysis.
\end{abstract}

Keywords: Regional geography, Geography of the countries, curriculum, the problematic approach, algorithm, school geographical education

\section{INTRODUCTION}

The study of regional geography based on interaction and interdependence, territories and common problems, distinguished by specific development and policy is a proof that school geography is one of the subjects with the world outlook for global issues and sustainable development, to the dynamics of economic development and contradictions. The study of Regional geography in high school Bulgaria and Macedonia and the comparative analysis lies not only in the framework of the curricula and syllabuses, and cover the geographical methodical and didactic teaching spaces and content.

The study of geographic regions and disclosure of complex influence of natural, historical, economic, demographic and political factors in the formation regions in Europe, Asia, America, Africa, Australia and Oceania, as well as assessing the importance of Regional geography and studying in secondary school is one of the latest and modern aspects of school geographical education.

The comparison is based on curriculums and syllabuses in compulsory training on the following criterions: year of introducing the curriculums, weekly and annual total number of classes, cultural-educational fields, structure and content of regional geography, site of the regional course in high education, name of the school subject and section, goals and correlations, didactic guidelines and more.

From August 1, 2016 in Bulgaria is introduced a new law - Law on pre-school and school education, as well as established new syllabuses (in stages with effect from the school year 2016/2017, 2017/2018, 2018/2019) the school subjects, including Geography and economics. From November 30, 2015 are introduced new syllabuses, in which changed the site structure and content of school geographical education - Ordinance № 4 / 
30.11.2015 on the curriculum. These new educational realities are reflected in the present study along with the now effective curriculum in Geography and economics for high education.

In Macedonia and Bulgaria and currently continues education reform that inherently affects the school geographical education. The Geography curriculum in Macedonia for the first year of high school, in which studies the regional part of May 2001, entered into force on September 1, 2001, functioning in the moment [1]. In Bulgaria the curriculum of Geography and economy for IX class, in which studies the regional geography since 2009 [2]. From the 2018/2019 school year will be introduced into force accepted a new curriculum for IX class, containing regional part [3].

Follow-up study of regional geography in high education of both countries put one an important educational accent that clearly stands out and has consequences for the overall study of the regional course of secondary and high education - compulsory school education. In Macedonia, secondary education is compulsory and from 2008 the high education is compulsory. In Bulgaria is compulsory only the secondary education (it graduated in VII grade under the new law), but the high is not mandatory. The study of the regional part of high education in Bulgaria can not be embraced by students who do not continue their education after graduation secondary school.

In Macedonia, the study of the school subject is named Geography and the high education includes regional geography - I year of high school (X class) after graduating secondary education (from VI to IX class including is studied geography and the secondary education ends at the IX class). Geography belongs to all three subject areas - NatureMathematics, Language-Arts and Social-Humanistic. The name of the school subject in Bulgaria is Geography and economics, but that is not explained in any regulatory document that name. The school subject Geography and economics in cultural and educational field belongs to the Social sciences and civic education, religion. In Bulgaria secondary education ends in VII grade, into force from school year 2016/2017, and the study of regional geography in high education in IX class or this is the second year of the first upper-high level. The discrepancy is with one year in the study of regional geography in high education on both countries, but in the next class of compulsory geographical education in both countries is completed by studying the native geography.

In Macedonia, the section on curriculum, including regional part is named Politicogeographical characteristics of the world, with a certain number of school classes $3+1$, which is $5.6 \%$ of the total annual number of school classes (first year high education 72 hours of total annual number) [1, 4]. A little time spent studying is explained by the fact that pupils in VIII and IX class study detailed regions and countries. In Bulgaria the core in curriculum of the educational content is № 4 -Geographical regions in the world and the countries in them (IX class is - 54 hours of total annual number) [2].

Both countries curricula includes five main themes to varying degrees encompass the study of geography of the countries. In Macedonia, the five topics listed only one is a direct reflection of teaching regional geography - Politico-territorial division of the world (Europe, Asia, Africa, North America, South America, Australia and Oceania).

In Bulgaria, the five main topics are carriers of regional knowledge or $16.7 \%$ of the total school content, but four of the topics are directly related to the essence and content of regional geography. In the curriculum of Geography and economics does not contain the number of school classes for the study of the regional part.

Differences in the weekly and annual number of school classes in the class, in which studies the regional geography about the reflects over its structure and content. In 
Macedonia the educational content in the first year of high school is studying 2 hours per week and 72 hours per year, and in Bulgaria is 1.5 hours per week and 54 hours per year $[1,2,4]$.

Table 1. Section and main themes in the study of regional geography in high education in Macedonia and Bulgaria on curriculums

\begin{tabular}{|c|c|c|c|}
\hline COUNTRY & $\begin{array}{l}\text { MAIN } \\
\text { THEMES } \\
\text { /CORE/ }\end{array}$ & TOPICS & $\begin{array}{c}\text { NUMBER } \\
\text { OF } \\
\text { SCHOOL } \\
\text { CLASSES }\end{array}$ \\
\hline \multirow[t]{5}{*}{ MACEDONIA } & \multirow{5}{*}{$\begin{array}{l}\text { Politico- } \\
\text { geographical } \\
\text { characteristi } \\
\text { cs of the } \\
\text { world }\end{array}$} & $\begin{array}{l}\text { 1. National political systems (countries, nations } \\
\text { and national systems) }\end{array}$ & \multirow[t]{5}{*}{$3+1$} \\
\hline & & 2. Development of modern countries & \\
\hline & & $\begin{array}{l}\text { 3. Geographical characteristics of the countries } \\
\text { (size, shape, position, limits) }\end{array}$ & \\
\hline & & $\begin{array}{l}\text { 4. Politico-territorial division of the world } \\
\text { (Europe, Asia, Africa, North America, South } \\
\text { America, Australia and Oceania) }\end{array}$ & \\
\hline & & $\begin{array}{l}\text { 5. International political systems and regional } \\
\text { groupings (Organization of United Nations, } \\
\text { regional economic groupings) }\end{array}$ & \\
\hline \multirow[t]{7}{*}{ BULGARIA } & \multirow{5}{*}{$\begin{array}{l}\text { Geographica } \\
\text { l regions in } \\
\text { the world } \\
\text { and the } \\
\text { countries in } \\
\text { them }\end{array}$} & 1. Regional geography & \multirow[t]{5}{*}{-} \\
\hline & & $\begin{array}{l}\text { 2. Geographic regions in Europe, Asia and } \\
\text { America }\end{array}$ & \\
\hline & & $\begin{array}{l}\text { 3. Economic development of regions and } \\
\text { countries in them }\end{array}$ & \\
\hline & & $\begin{array}{l}\text { 4. Countries - typical representatives of the } \\
\text { region }\end{array}$ & \\
\hline & & $\begin{array}{l}\text { 5. The global problems of modern times and their } \\
\text { manifestation by regions. }\end{array}$ & \\
\hline & \multirow[b]{2}{*}{$\begin{array}{l}\text { Geography } \\
\text { of the } \\
\text { continents } \\
\text { and the } \\
\text { countries } \\
\text { (In force as } \\
\text { from school } \\
\text { year } \\
2018 / 2019 \text { ) }\end{array}$} & 1. Regional geography. European region. & \multirow[t]{2}{*}{-} \\
\hline & & $\begin{array}{l}\text { 2. Regions - Asia, North and South America, } \\
\text { Africa and Australia and Oceania }\end{array}$ & \\
\hline
\end{tabular}

On indicator of consistency of the studied regions and countries by continents has an identical structure as the place of Africa and America is exchanged (Figure 1.). In both countries observed the territorial principle of learning regions and countries. 


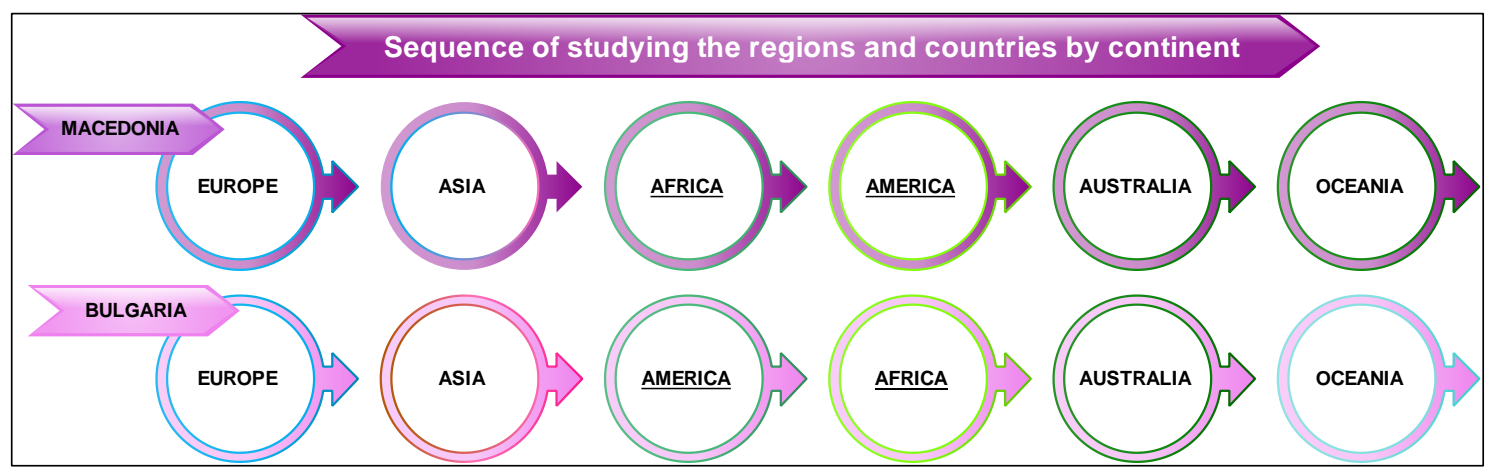

Figure 1. Sequence of continents in the study of regions and countries (on curriculum) in Macedonia and Bulgaria

In Bulgaria to theme 4. Countries - typical representatives of the certain region of the curriculum in Geography and economy IX class no example indicated of any country for study to a region and continent. In the new curriculum, which will be into force from 2018/2019 school year, there were certain expected results, which are pointing to characterize the selected countries on rule and concrete examples: Europe - Germany, France, Russia; Asia - Japan, China, India; North and South America: USA, Brazil; Africa - Republic of South Africa; Australia and Oceania - Australian Union [1, 3].

In Macedonia, the specific goals for pupils and didactic remarks to the teachers has certain countries - examples of such representatives - Figure 2. The specific goals for pupils are determined to make a characteristic of the country from each continent. To didactic remarks about teachers is determined for each continent to make a characteristic of the country, which are given specific examples. There is some discrepancy in these examples of countries that could be explained by the choice and the freedom of pedagogical specialists and interests of pupils.

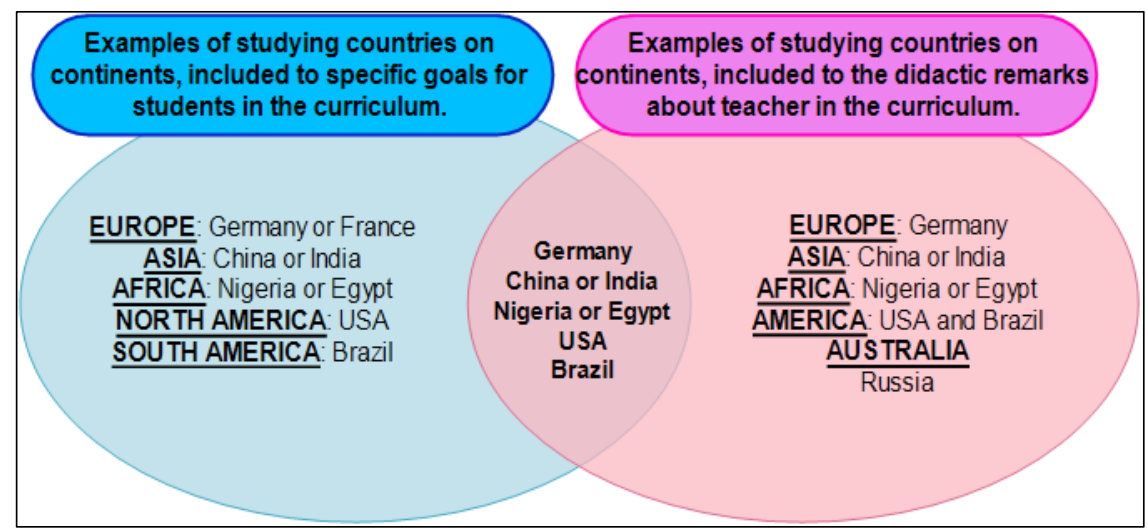

Figure 2. Venn-diagram for example countries - typical representative for study to a certain continent by curriculum on Geography in Macedonia

In Figure 3 is evident eligibility for pupils and teachers to study country by continents. Both countries categorically is definitely the place to study the United States, Brazil and Russia, but not on a selective basis. In the new curriculum on geography in Bulgaria are features three countries identified for the study, which lack examples in the curriculum of Macedonia - Japan, Republic of South Africa and Australian Union. Their distinguishing and learning of Nigeria or Egypt indicated to the curriculum of Macedonia is explained by the varying speed of education reforms in both countries and the new realities in the update of geographical knowledge in the field of geographical science. 
The curriculum in Macedonia and the new in Bulgaria are direct application of the typological principle at study regional geography. In both curriculums in geography are certain countries that are typical representatives for the region.

The advantage of these new curriculum on Geography and economy in Bulgaria are examples of countries by continents, as well as the expected result for presentation of geographical characteristics of countries in the regions of choice, including using the ICT [2].

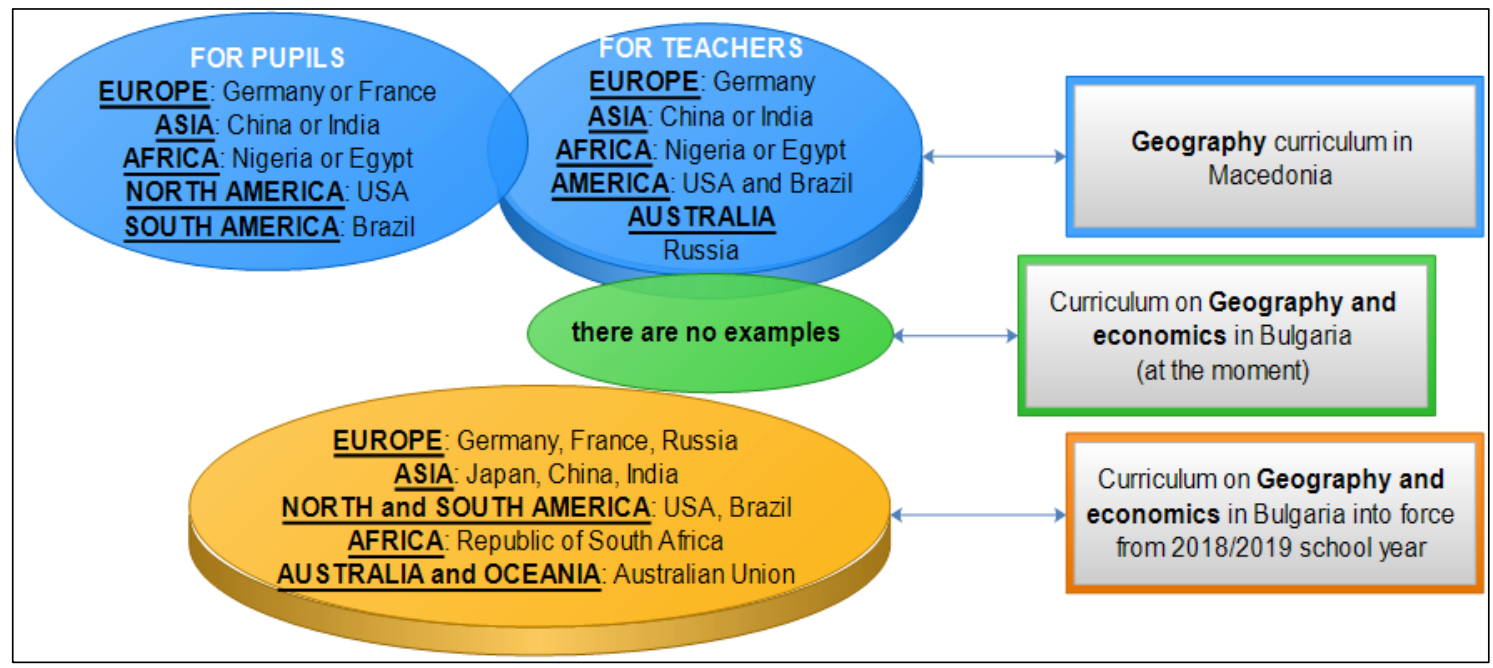

Figure 3. Examples of countries defined on curriculums for learning by continents in Macedonia and Bulgaria

In the current curriculum in Geography and economics in Bulgaria has placed accent in addition to territorial and typological principle and the problem approach to the study of regional geography.

In curriculums in the study of regional geography are included specific new concepts with different numbers and commitment with the topics section - Figure 4. Geography curriculum in Macedonia is not indicated to new concepts in the studying of regional geography. In the present state curriculum on Geography and economics in Bulgaria has indicated two concepts that are only $4 \%$ of the total number of basic concepts by cores: geographic regions and regional geography. In the new curriculum for IX class, which will be in force from 2018/2019 school year, were down a total of 3 concepts to topic Geography of continents and countries, or $7 \%$ of the total number of new concepts by topics. The three new concepts are fully committed to the study of regional organizations. In all three curriculums have not match with the new concepts in the study of regional geography $[1,2,3]$.

The comparative analysis includes the algorithm / rule or guideline for using and applying the algorithm for characterize the region or country in the curriculums of both countries in the study of regional geography. 


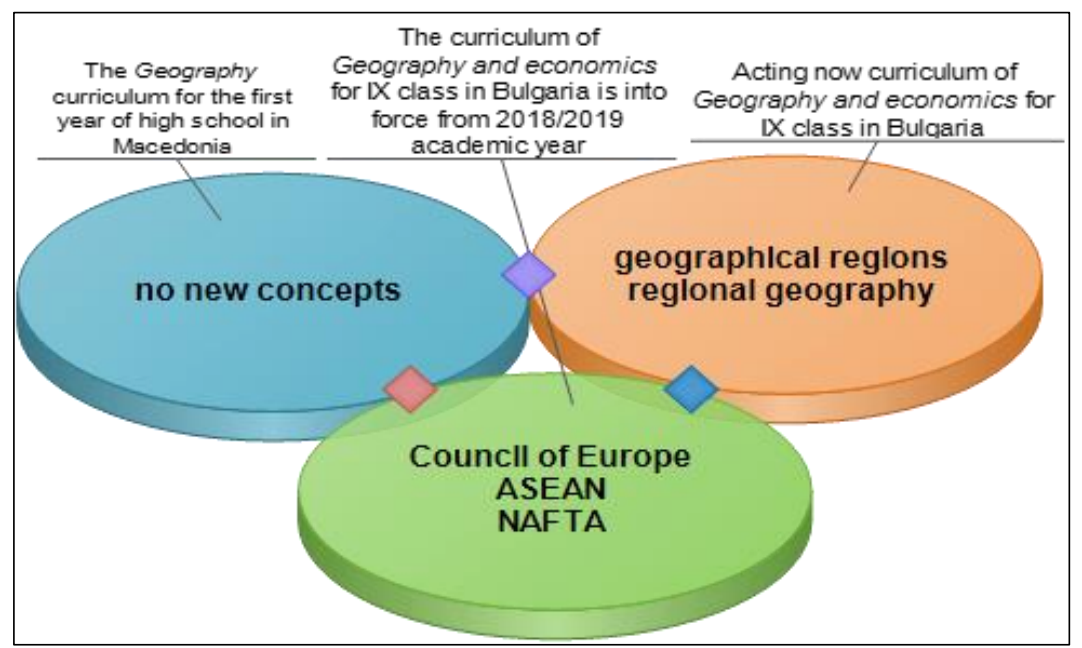

Figure 4. New concepts in the study of regional geography by curriculums in Macedonia and Bulgaria

In the curriculum on Geography for first year of high school in Macedonia has not specified algorithm to characterize the country. The advantage is the availability of support knowledge, didactic notes to the teacher, educational resources and materials, standard geographical office and pedagogical cadre.

In the present state curriculum on Geography and economics in Bulgaria for IX class has recorded expected result on topic № 4: Countries - typical representative of the region,1. Knows the algorithm for characteristic of countries." Partially specified sequence of studying the geographical region and in theme № 2: Geographical regions in Europe, Asia and America, as expected result is written ,,1. Expose knowledge for specific in nature, population and economy of each region." "[2].

In the curriculum on Geography and economics into force from 2018/2019 school year, is contained in the topic on Geography of continents and countries specific rule competence as an expected result of the training for the European region:

is characterized the European region as a rule: geography location, natural environment, population, economy, specific problems;

\& characterized selected countries (Germany, France, Russia) on rule: geographic location, natural environment, population, economy and cities.

For regions - Asia, North and South America, Africa, Australia and Oceania is defined:

\& characterized regions on rule: geographic location, natural environment, population, economy, specific problems;

(3) characterized selected countries in the regions: Asia (Japan, China, India), North and South America (USA, Brazil), Africa (Republic of South Africa), Australia and Oceania (Australian Union) on rule.

In both countries is paid attention to supporting knowledge that lay the foundations of studying Regional geography in high education. On Figure 5 is a representative supporting knowledge on both countries by curriculums. The diversity of learning the continents in both countries from Africa to Europe and from Europe to Africa are identify the differences in scientific-methodological foundations of geographical science $[1,2,5$, $6,7,8]$. 


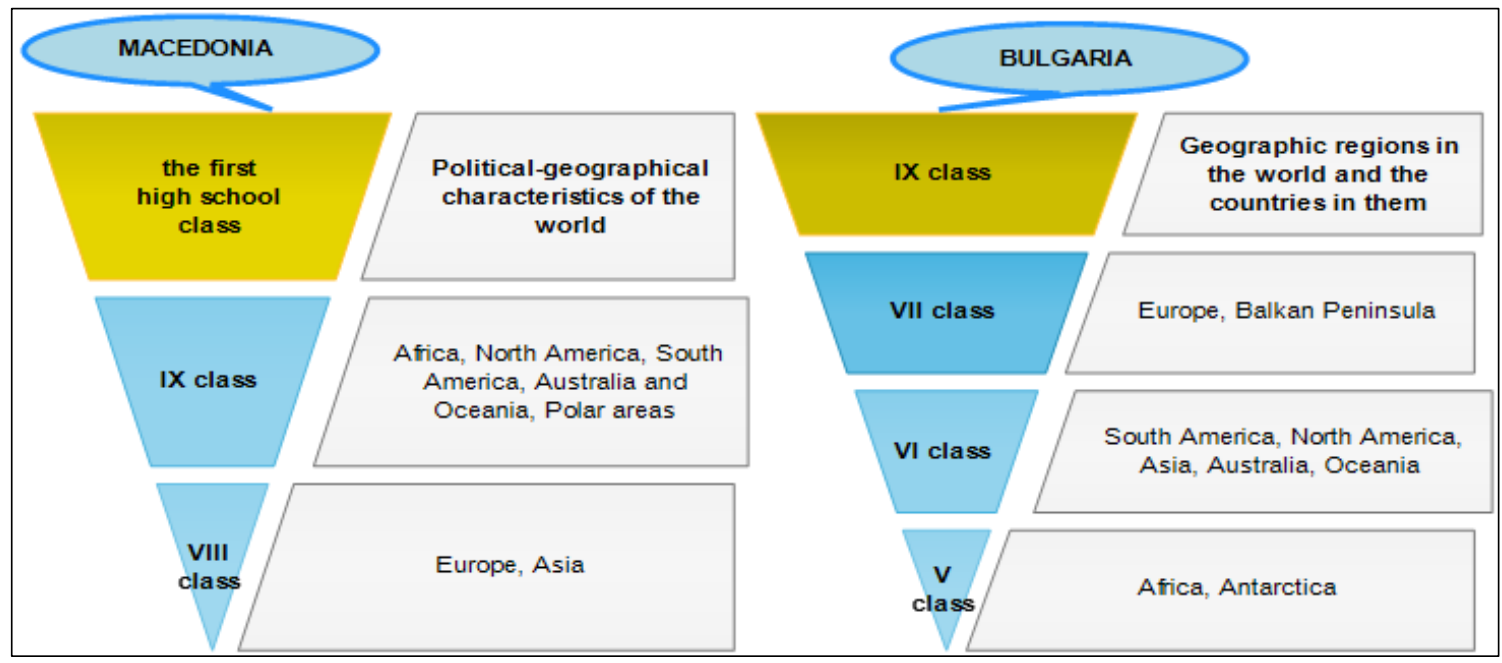

Figure 5. Supporting knowledge for the study of regional geography in high education in Macedonia and Bulgaria on curriculums

The implementation of inside-school subject and interdisciplinary relations and correlations are defined in Figure 6. With the new curriculum in Geography and economy in Bulgaria in the interdisciplinary relations by the key competences are in respective with European and in the present curriculum for IX class is only a correlation - history. Single parallel to both countries in the use of interdisciplinary relations has only for the school subject - history $[1,2,3]$.

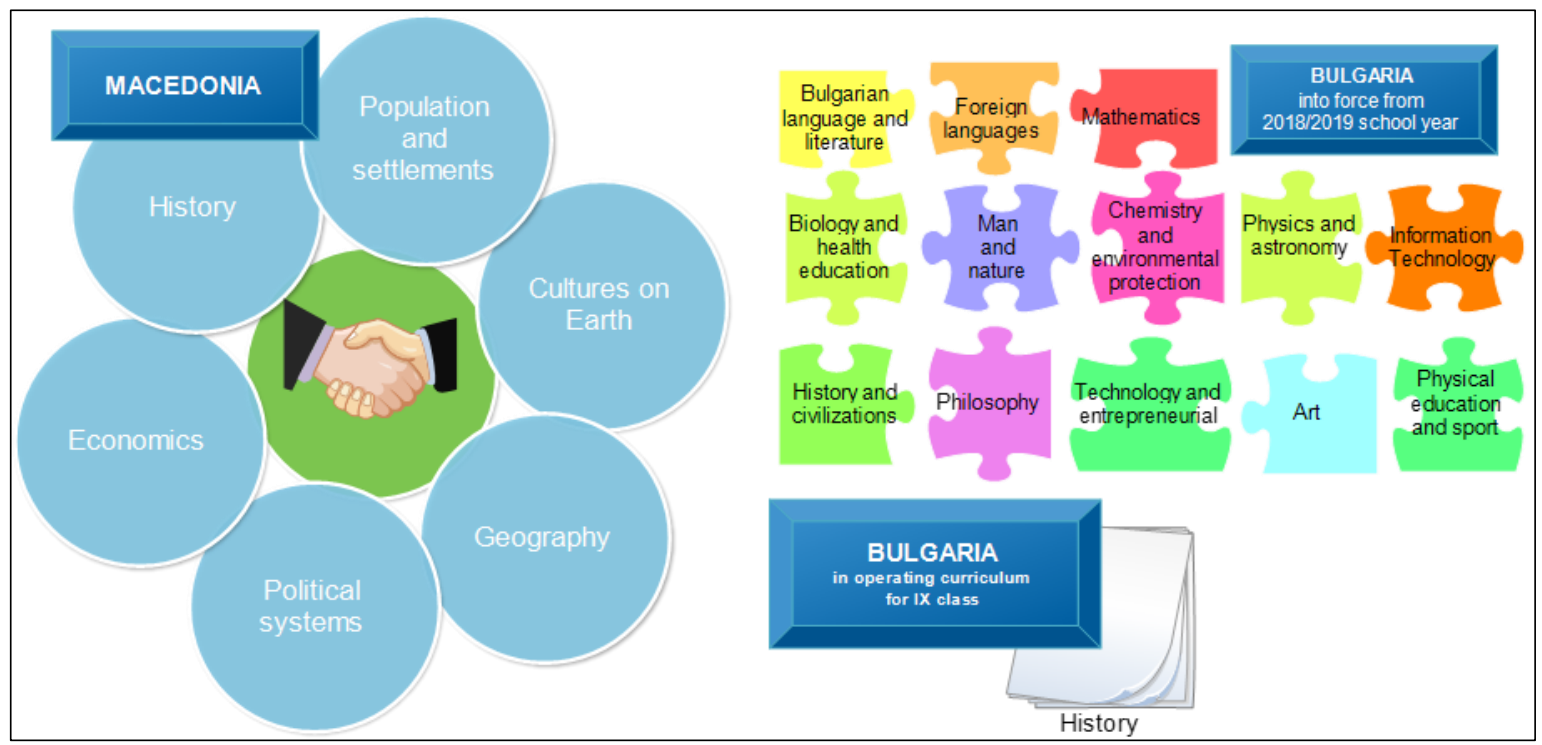

Figure 6. Vertical and horizontal links of regional geography in high education curriculums in Macedonia and Bulgaria

In Macedonia has accepted Assessment standards that clearly define the level of knowledge and skills and for regional geography in the first year of high education (Table 2) [9]. 
Cartography, GIS and Spatial Planning, Teaching and educational geography

Table 2. Assessment standards for „Politico-geographical characteristics of the world" for the first year of high education in Macedonia

\begin{tabular}{|c|l|}
\hline $\begin{array}{c}\text { Level of knowledge } \\
\text { and skills }\end{array}$ & \multicolumn{1}{c|}{ Standard } \\
\hline knowledge & $\begin{array}{l}\text { - to register the geographical characteristics of the countries; } \\
\text { - to memorize the politico-territorial division of the world; }\end{array}$ \\
\hline understanding & $\begin{array}{l}\text { - with own words to express politico-territorial division of the world; } \\
\text { - to discuss the geographical characteristics of the countries; }\end{array}$ \\
\hline application & $\begin{array}{l}\text { - to register the geographical characteristics of the countries; } \\
\text { - to memorize the politico-territorial division of the world; }\end{array}$ \\
\hline $\begin{array}{c}\text { analysis, synthesis, } \\
\text { assess }\end{array}$ & $\begin{array}{l}\text { - to combine the geographical characteristics of the countries; } \\
\text { - to draw up a politico-territorial division of the world. }\end{array}$ \\
\hline
\end{tabular}

In Appendix № 9 of Ordinance № 5 / 30.11.2015 on general educational preparation in Bulgaria are ranked for first high school stage in expected results of the training at the level of knowledge, skills and attitudes (the new curriculum „Geography of regions and countries") - ,, describes the regional division of the world; characterized by an algorithm specific features of the regions in the world; comment the peculiarities of natural, demographic and economic outlook of the country, typical representatives of the regions in the world" [10].

The Geography curriculums in both countries have spiral-concentric and linear structure, which is ensuring successively and concentricity, orderliness and continuity, unfolded and complexity of the learning process in regional geography.

Applying the problematic approach to studying the geography of countries and the algorithm as his reflection should be in accordance with educational standards. They must be directed towards revealing and discussing territorial manifestation of the problems of each region or country, outlining specific problems and explaining the reasons for their occurrence. Characterization of selected countries in the regions based on the problematic approach directed to detecting unique in its natural, demographic and economic outlook.

\section{REFERENCES}

[1] Uchebna programa za I godina gimnaziya, Republic of Macedonia, 2001, pp 1-13.

[2] Uchebna programa po geografiya i ikonomika - IX klas, zadalzhitelna podgotovka, Republic of Bulgaria, 2009.

[3] Uchebna programa po geografiya i ikonomika za IX klas, Republic of Bulgaria, 2015.

[4] Uchebni planove za gimnazialno obrazovanie, Republic of Macedonia.

[5] Uchebna programa po geografiya za VI klas, Devetgodishno osnovno obrazovanie, Skopie, Republic of Macedonia, yanuari 2015.

[6] Uchebna programa po geografiya za VII klas, Devetgodishno osnovno obrazovanie, Skopie, Republic of Macedonia, yanuari 2015.

[7] Uchebna programa po geografiya za VIII klas, Devetgodishno osnovno obrazovanie, Skopie, Republic of Macedonia, 2008.

[8] Uchebna programa po geografiya za IX klas, Devetgodishno osnovno obrazovanie, Skopie, Republic of Macedonia, 2009.

[9] Standarti za gimnazialno obrazovanie, Republic of Macedonia http://bro.gov.mk/?q=gimnazisko-obrazovanie-standardi.

[10] Naredba № 5/30.11.2015 za obshtoobrazovatelnata podgotovka, Republic of Bulgaria, 2015. 